\title{
Surfactant Assisted Separation-Spectrophotometric Procedure for the Trace Analysis of Copper (II) in Drug and Water Samples Using a Heterocyclic Pyridyl Azo Dye
}

\section{Magda A AkI*, Magdy M Bekheit and Qasim Mezban Salih}

Chemistry Department, Mansoura University, Mansoura, Egypt

\begin{abstract}
4-(2-pyridyl-Azo) resorcinol mono sodium mono hydrate (NaPAR), a heterocyclic azo dye, was investigated for the flotation of copper (II). The metal ion forms a faint red complex with NaPAR in aqueous solution. An intense clear red layer was formed in the scum, after flotation, by adding an oleic acid (HOL) surfactant. The composition of the float is 1:2 (Cu(II): NaPAR). A highly selective and sensitive spectrophotometric procedure was proposed for the determination of micro-amounts of $\mathrm{Cu}(\mathrm{II})$ as its floated complex in the $\mathrm{pH}$ range 3.0-5.0. Beer's law was obeyed up to $5 \times 10^{-5} \mathrm{~mol} \mathrm{l}^{-1}$. The Interferences from various foreign ions were avoided by adding excess NaPAR. The molar absorptivities of Cu-NaPAR and Cu-NaPAR-HOL systems are $5.3 \times 10^{4}$ and $6.1 \times 10^{5} \mathrm{~mol}^{-1} \mathrm{~cm}^{-1}$ for the colored complexes in the aqueous and scum layers, respectively. The Cu-NaPAR complexes formed in aqueous solution and in the $\mathrm{HOL}$ were characterized by infrared spectral studies. The method was successfully applied to the analysis of $\mathrm{Cu}(\mathrm{II})$ in water and drug samples with a recovery $>95 \%$ and a $\mathrm{RSD}<1.5 \%$. The separation mechanism is explained.
\end{abstract}

Keywords: Copper; 4-(2-pyridyl-azo) resorcinol mono sodium mono hydrate (NaPAR); Flotation; Spectrophotometry; Drugs

\section{Introduction}

Heavy metals are of the great importance for the life. Some of these such as $\mathrm{Cu}, \mathrm{Zn}, \mathrm{Co}, \mathrm{Fe}$ are essential to humans [1]. Others such as $\mathrm{Hg}, \mathrm{Cd}$ and $\mathrm{Pb}$ are toxic following occupational and environmental exposure [2].

Copper is one of the several metal ions that play an important role in the biological system. It performs a key role during cell respiration, in the blood of invertebrate animals and in the formation of haemocyanin [3]. Apart from the biological utility of copper, it also finds applications in industries [4]. It is used in the electrical industry as fine wires, commuter bars and high conductivity tubes. It is also used in pipe making, roof sheeting, bronze paints and insecticides. In addition, it is a hazardous pollutant in the environment, resulting from the industrial effluents, in the form of particulate or soluble copper waste from electroplating, chemical and textile industries. As a pollutant, copper is of particular concern, because of the high degree of toxicity to aquatic organisms. In view of this, separation and determination of copper from associated elements is indispensable.

Due to the low concentration of the heavy metals in the environmental and biological samples and interfering effects, a preconcentration/separation technique is generally necessary prior to the determination. For this purpose, various analytical procedures have been used, such as adsorption on activated carbon $[5,6]$ coprecipitation $[7,8]$ column extraction $[9,10]$ ion-selective electrode $[11,12]$ liquid-liquid extraction (LLE) [13], cloud point extraction[14] and flotation [15-26].

Flotation has attracted considerable attention mainly because it complies with the "Green Chemistry" principle [27], as the amount of organic solvent is much less than that of traditional liquid extraction. Moreover, It is simple, cheap, highly efficient, fast, and of lower toxicity than those extractions that use organic solvents. Flotation has been applied for separation and pre-concentration of some metal ions such as $\mathrm{Hf}$ and $\mathrm{Zr}$ in real samples [15,16], $\mathrm{Cu}$ in environmental, human blood and drug samples [17,26], Cd in environmental samples [18], lanthanum and yttrium in some geological and environmental samples $[19,20]$, vanadium(IV) in wastes of Power Stations [21], Selenium(IV) in Food Stuffs [22], Zinc(II) in Human Biofluids and Environmental Samples [23], iron(III) in water, real samples and wastes of power stations [24] and Sc3+ in certified materials and different water resources [25].

Since 1960, derivatives of 2-pyridylazo have been extensively studied for analytical purposes. A very important example is 4-(2-pyridylazo)resorcinol, PAR. This is an excellent metallochromic indicator and also very useful as a chromogenic agent for the quantitative determination of over 50 elements, including at trace levels $[28,29]$. PAR, C11H9N3O2, is commercially available as the free dye in the protonated form (represented as $\mathrm{H} 2 \mathrm{~L}$ ) or as the monosodium (NaHL.H2O) or disodium salt (Na2L.2H2O). PAR behaves as a tetradentate or a bidentate ligand to form soluble or insoluble colored complexes with cations of different heavy metals at specific $\mathrm{pH}$ values.

Among various instrumental methods of analysis, spectrophotometry is preferred as a versatile technique in exploring the use of 4-(2-pyridylazo)-resorcinol, (PAR) as an effective reagent to detect and determine copper (II) at micro level after floatation using oleic acid (HOL) surfactant, in diverse materials and substances. Further, the color of the floated metal complex is found to remain stable

*Corresponding author: Magda AAkl, Professor of Analytical Chemistry, Chemistry Department, Mansoura University, Mansoura, Dakahlia Governorate 35516, Egypt, Tel: 0020502217833; E-mail: magdaakl@yahoo.com

Received July 10, 2015; Accepted September 28, 2015; Published September 30, 2015

Citation: AkI MA, Bekheit MM, Salih QM (2015) Surfactant Assisted SeparationSpectrophotometric Procedure for the Trace Analysis of Copper (II) in Drug and Water Samples Using a Heterocyclic Pyridyl Azo Dye. Pharm Anal Acta 6: 421. doi:10.4172/21532435.1000421

Copyright: (c) 2015 Akl MA, et al. This is an open-access article distributed under the terms of the Creative Commons Attribution License, which permits unrestricted use, distribution, and reproduction in any medium, provided the original author and source are credited. 
for a considerable period, which sometimes extends even more than " 72 $h$ ". Hence, the investigators are encouraged to develop a sensitive and rapid spectrophotometric method for copper (II). The results obtained through UV-VIS spectrophotometer have been compared with those obtained through the atomic absorption spectrometer.

In the present study, a simple, rapid and economical flotation - spectrophotometric method has been developed for the preconcentration and determination of trace $\mathrm{Cu}(\mathrm{II})$ in different matrices using HOL as a surfactant and NaPAR as a chelating reagent. This reagent is more sensitive and specific than many of the reagents reported for $\mathrm{Cu}(\mathrm{II})$ [30-34]. Moreover, this method involves the determination of trace $\mathrm{Cu}(\mathrm{II})$ after selective separation by flotation, thus eliminating the effect of foreign ions and increasing the sensitivity. Also, the direct determination of $\mathrm{Cu}(\mathrm{II})$ in the surfactant phase decreases its determination time and loss during the determination.

A literature survey showed that ion-flotation followed by a spectrophotometric determination of $\mathrm{Cu}(\mathrm{II})$ is rarely reported $[17,26]$. Also, no attempt has been found for using NaPAR and oleic acid in this concern. Fortunately, in this work, NaPAR finds its role for a direct spectrophotometric determination of $\mathrm{Cu}(\mathrm{II})$ and also gives high performance in the pre-concentration of $\mathrm{Cu}(\mathrm{II})$ via its flotation as $\mathrm{Cu}(\mathrm{II})-\mathrm{NaPAR}$ colligend.

\section{Materials and Methods}

\section{Chemicals and solutions}

Unless otherwise specified, all chemicals used are of analyticalreagent grade. Doubly distilled water (DDW) was used throughout. A stock solution of Copper $(1 \mathrm{mg} / \mathrm{ml})$ was prepared by dissolving $\mathrm{CuSO} 4$ in double distilled water and a few drops of concentrated sulphuric acid ere added. The final concentration of $\mathrm{Cu}(\mathrm{II})$ was standardized using an atomic-absorption spectrometer. Monosodium salt of 4-(2-pyridylazo) resorcinol, NaPAR, was purchased from Sigma Aldrich. Stock solution $\left(1 \times 10^{-3} \mathrm{~mol} \mathrm{l}^{-1}\right)$ was prepared by dissolving the requisite amount of NaPAR in DDW. Oleic acid stock solution (6.36 x $10^{-2} \mathrm{~mol} \mathrm{l}^{-1}$ was prepared by dispersing $20 \mathrm{ml}$ of HOL (food grade) sp.gr. 0.895 , provided by J.T. Baker Chemical Co.) in one 1 of kerosene. One liter of tap, Nile or sea water samples was filtered off, adjusting the $\mathrm{pH}$ to 1 with concentrated $\mathrm{HCl}$, to prevent losses by sorption or coprecipitation, and preserved in a high quality clean plastic containers. Vita stress and Totavit tablets, multiminerals general tonics containing copper available in the Egyptian market, were analyzed to determine the copper content in each drug using the proposed methodology. Exactly $40 \mathrm{mg}$, each of the drug samples was taken, crushed and heated in $5 \mathrm{ml}$ concentrated $\mathrm{HNO}_{3}$ for dissolution. The cold solution was filtered, collected in a 50- ml calibrated flask and completed to the mark with DDW.

\section{Apparatus}

Flotation cells: Two types of flotation cells were used throughout this work, as has already been described [35]. Flotation cell (a) is a cylindrically graduated glass tube of $16 \mathrm{~mm}$ inner diameter and 290 $\mathrm{mm}$ length with a stopcock at the bottom. Such cell is used to study the different factors affecting the efficiency of flotation. Flotation cell (b) is a cylindrical tube of $6 \mathrm{~cm}$ inner diameter and $45 \mathrm{~cm}$ length with a stop cock at the bottom and a quick fit stopper at the top. This cell is used to separate copper from 1 liter of different water samples. The spectral data were recorded on Unicam UV 2100 UV/ Vis and MATTSON 5000 FTIR spectrometers. The atomic-absorption measurements were recorded using a Perkin-Elmer 2380 Atomic- absorption Spectrophotometer with an air-acetylene flame. The optimum parameters for $\mathrm{Cu}$ measurements are $324.7 \mathrm{~nm}$ wavelength; lamp current, $4 \mathrm{~mA}$; burner height, $0.9 \mathrm{~cm}$; slit width, $0.7 \mathrm{~mm}$; fuel flow rate, $31 \mathrm{~min}^{-1}$; and air flow rate, $21 \mathrm{~min}^{-1}$. The $\mathrm{pH}$ values of all solutions were measured using a Hanna Instruments 8519 digital pH meter.

Analytical procedures: Suitable concentrations of $\mathrm{Cu}(\mathrm{II})$ and NaPAR were mixed, $3 \mathrm{ml}$ of DDW was added and the $\mathrm{pH}$ was adjusted to the optimum value (4.0). The solution was then transferred quantitatively to a flotation cell and completed to $10 \mathrm{ml}$ with DDW. The cell was shaken well for few seconds to ensure complete complexation. To this solution, $3 \mathrm{ml}$ of $\mathrm{HOL}\left(10^{-4} \mathrm{~mol} \mathrm{l}^{-1}\right)$ was added. The flotation cell was then inverted upside down twenty times by hand. After complete floatation $(10 \mathrm{~min})$ the scum layer was separated and taken for the determination of $\mathrm{Cu}(\mathrm{II})$ spectrophotometrically at $510 \mathrm{~nm}$ and confirmed by flame atomic-absorption (AAS) after eluting the analyte with a few drops of $\mathrm{HNO}_{3}$ or $\mathrm{HCl}$.

The separation efficiency was calculated from the relation:

$$
\mathrm{F}=\left(\mathrm{c}_{\mathrm{s}} / \mathrm{c}_{\mathrm{i}}\right) \times 100 \%
$$

where $c_{i}$ and $c_{s}$ is the initial and scum concentrations of the analyte, respectively.

Alternatively, $\mathrm{Cu}(\mathrm{II})$ was determined directly by AAS in the mother liquor. The separation efficiency (S\%) of the analyte was calculated from its concentration in the mother liquor according to the relation

$$
\mathrm{S}=\left[\left(\mathrm{c}_{\mathrm{i}}-\mathrm{c}_{\mathrm{f}}\right) / \mathrm{c}_{\mathrm{i}}\right] \times 100 \%
$$

where $c_{i}$ and $c_{f}$ denote the initial and final concentrations of the analyte, respectively.

\section{Results and discussion}

\section{Absorption spectra}

The absorption spectra of the $\mathrm{Cu}(\mathrm{II})$-NaPAR system in the aqueous solution and in the scum layer are completely different from that of copper and NaPAR (Figure 1). It is observed that: 1 ) the $\lambda_{\text {max }}$ of $\mathrm{Cu}(\mathrm{II})$ NaPAR exhibits a red shift $(100 \mathrm{~nm})$ from that of NaPAR and 2) the absorbance of $\mathrm{Cu}$ (II)-NaPAR-HOL system exhibits nearly 10 -folds that of $\mathrm{Cu}(\mathrm{II})-\mathrm{NaPAR}$. This proves that the species are highly concentrated in the presence of HOL.

\section{Separation and microdetermination of $\mathrm{Cu}(\mathrm{II})$}

Effect of pH: A conductive series of experiments was carried out to float $\mathrm{Cu}$ (II) using HOL alone. A suitable concentration of the analyte $\left(2 \times 10^{-5} \mathrm{~mol} \mathrm{l}^{-1}\right)$ was taken in the floatation cell and a sufficient quantity of HOL surfactant $\left(2 \times 10^{-4} \mathrm{~mol} \mathrm{l}^{-1}\right)$, which is still less than the critical micelle concentration (CMC) was added to float $\mathrm{Cu}$ (II) at different $\mathrm{pH}$ values. The data in Figure 2 (curve a) prove that not more than $20 \%$ of the analyte was separated at any $\mathrm{pH}$. Such a separation percent is not analytically satisfactory in which $\mathrm{Cu}$ (II) floats as $\mathrm{Cu}$ oleate [36]. Accordingly, many trials were carried out to separate $\mathrm{Cu}$ (II) quantitatively and selectively using different organic collectors. Of these, NaPAR imposed itself as an excellent collector. The data in Figure 2 (curve $b$ ) show that complete separation $(\approx 100 \%)$ of $\mathrm{Cu}(\mathrm{II})$ was obtained in the 3-5 pH range in the presence of $2 \times 10^{-4} \mathrm{~mol} \mathrm{l}^{-1}$ of NaPAR. In such a case, $\mathrm{Cu}$ (II)floats in the form of the $\mathrm{Cu}-\mathrm{NaPAR}$ complex as an intense red color.

Effect of ligand concentration: The data in Figure 2 show that complete separation of the analyte is achieved over a wide range of $\mathrm{pH}$. The direct addition of the reactants acquires the solution $\mathrm{pH}=4.0$. 


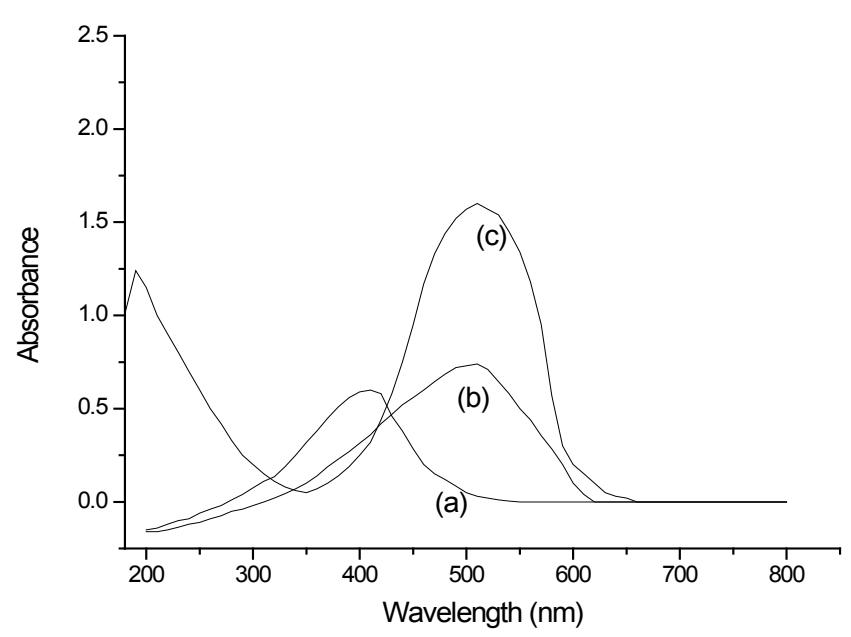

Figure 1: Absorption spectra of: a) The reagent NaPAR, b) Cu-NaPAR system and c) Cu-NaPAR-HOL system.

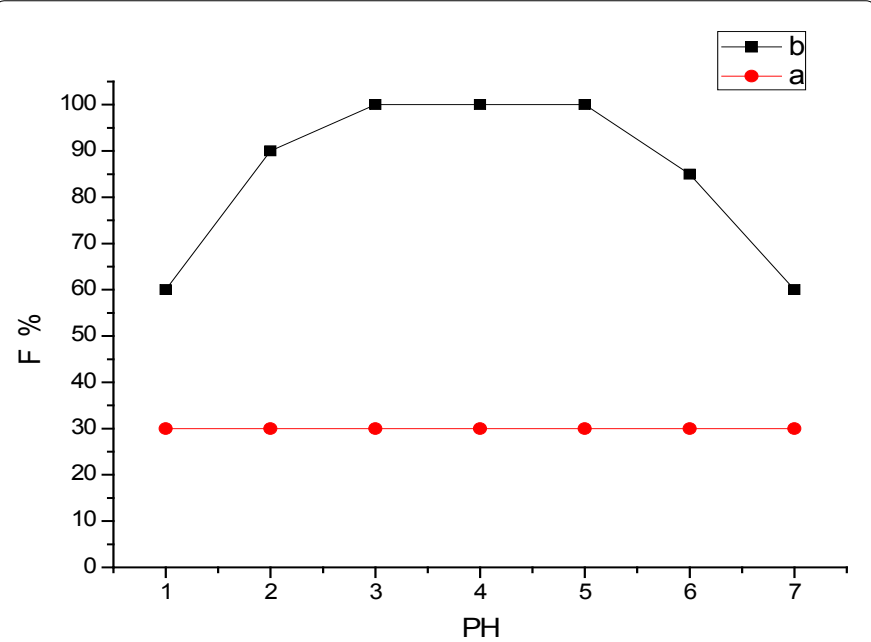

Figure 2: Effect of the $\mathrm{pH}$ on the separation efficiency of $2 \times 10^{-5} \mathrm{~mol} \mathrm{l^{-1 }} \mathrm{Cu}(\mathrm{II}) \mathrm{a}$ In the absence of NaPAR, b) In the presence of $2 \times 10^{-4} \mathrm{~mol} \mathrm{I}^{-1} \mathrm{NaPAR}$, using 2 x $10^{-4} \mathrm{~mol} \mathrm{I}^{-1} \mathrm{HOL}$.

Accordingly, $\mathrm{pH} 4.0$ is selected as a suitable value for complete separation to facilitate the proposed afford due to the progress in this work. At such $\mathrm{pH}$ a conductive series of experiments was carried out to investigate the type of interaction between $\mathrm{Cu}(\mathrm{II})$ and $\mathrm{NaPAR}$ in solution. It was found that $\mathrm{Cu}(\mathrm{II})$ forms a 1:2 complex with $\mathrm{NaPAR}$, and complete floatation-separation was achieved whatever amount of NaPAR was added (Figure 3). This simplifies the procedure for the analytical separation and determination of $\mathrm{Cu}(\mathrm{II})$, especially in samples containing unknown amounts of the analyte.

Effect of metal concentration: To confirm the previous data, another series of experimental work was carried out by changing the metal concentration. The data (Figure 4) showed that complete separation occurred up to the previous ratio of 1:2. Above such a ratio of increasing $\mathrm{Cu}(\mathrm{II})$, curve (b) in Figure 4 attains a small degradation to a lower separation percentage. This reflects that insufficient ligand is present for complete complexation and indirect separation.

Effect of HOL concentration: The floatability of $\mathrm{Cu}(\mathrm{II})$ at different concentrations of HOL in the presence of NaPAR has been investigated, Figure 5. The floatability of $\mathrm{Cu}(\mathrm{II})$ slightly increases and reaches its maximum (100\%) over a wide concentration range of $\mathrm{HOL}$, and then slightly decreases. A $2 \times 10^{-4} \mathrm{~mol} \mathrm{l}^{-1} \mathrm{HOL}$ was used throughout this work.

Effect of temperature: A series of experiments was conducted in a wide temperature range $\left(20-80^{\circ} \mathrm{C}\right)$, to find out the proper temperature required for maximum flotation of $\mathrm{Cu}-\mathrm{NaPAR}$ complex. It was found that the flotation efficiency was not markedly affected in the $20-80^{\circ} \mathrm{C}$ range, (Figure 6). Therefore, subsequent measurements were carried out at room temperature, i.e., $\sim 25^{\circ} \mathrm{C}$.

Effect of shaking time : The influence of shaking time of the flotation cell on separation of $\mathrm{Cu}(\mathrm{II})$ using NaPAR $\left(4 \times 10^{-4} \mathrm{~mol} / \mathrm{L}\right)$ and $1 \times 10^{-4} \mathrm{~mol} / \mathrm{L}$ HOL was investigated (Figure 7). It was found that the flotation efficiency reaches its maximum $(\sim 100 \%)$ after about 2 minutes and remains constant up to $10 \mathrm{~min}$. Therefore, a shaking time of 3 minutes was used in the subsequent experiments to ensure complete metal separation. This means that the flotation separation procedure is not time consuming. In order to affirm the stability of the metal separation after $10 \mathrm{~min}$, complementary experiments were done from $10 \mathrm{~min}$ to $72 \mathrm{hr}$. It was found that color and the separation efficiency remain constant up to $72 \mathrm{hr}$.

Effect of ionic strength: Table 1 illustrates the effect of changing the ionic strength of different salts on the flotation efficiency of $2.0 \times 10$ ${ }^{5} \mathrm{M} \mathrm{Cu}(\mathrm{II})$ ions with $1.0 \times 10^{-4} \mathrm{M}$ HOL in the presence of $1.0 \times 10^{-4} \mathrm{M}$ $\mathrm{NaPAR}$ at $\mathrm{pH}$. The salts used in modifying the ionic strength usually look like individual salts present in natural water samples. As it can be noticed, the ionic strength of the medium has not evidently affected the flotation process or the determination of copper.

Effect of interfering ions: The effect of interfering ions on the floatability of $\mathrm{Cu}(\mathrm{II})$ with NaPAR has been studied in detail. The obtained results revealed that in spite of the high tendency of NaPAR to form complexes with different transition metal ions, fortunately, most of these complexes are not floated with the $\mathrm{Cu}(\mathrm{II})-\mathrm{NaPAR}$ complex at $\mathrm{Ph}$ : 3.0-5.0. The experimental data showed that $\mathrm{Na}(\mathrm{I}), \mathrm{K}(\mathrm{I}), \mathrm{Ag}(\mathrm{I})$, $\mathrm{Ca}(\mathrm{II}), \mathrm{Mg}$ (II), $\mathrm{Sr}(\mathrm{II}), \mathrm{Pb}(\mathrm{II}), \mathrm{Cd}(\mathrm{II})$ and $\mathrm{Ni}(\mathrm{II})$ as chlorides, sulphates or nitrates have no effect, whereas $\mathrm{Al}(\mathrm{III}), \mathrm{Hg}(\mathrm{II}), \mathrm{Fe}(\mathrm{III}), \mathrm{U}(\mathrm{IV})$, $\mathrm{V}(\mathrm{V})$ and $\mathrm{Os}(\mathrm{V})$ have little interfering effects $(\sim 1 \%)$. All of these interferences were completely controlled by adding excess NaPAR $(2 \mathrm{x}$

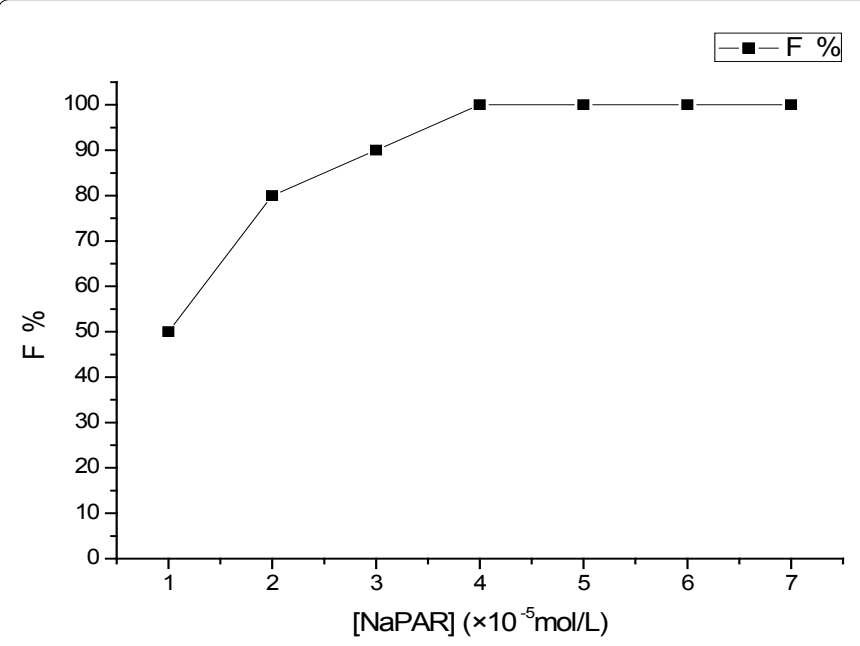

Figure 3: Floatability of $2 \times 10^{-5} \mathrm{~mol} \mathrm{I}^{-1}$ of $\mathrm{Cu}(\mathrm{II})$ at $\mathrm{pH} 4$ a) In the absence of $\mathrm{NaPAR}, \mathrm{b})$ In the presence of NaPAR using $2 \times 10^{-4} \mathrm{~mol} \mathrm{I}^{-1} \mathrm{HOL}$ at $\mathrm{pH} 4$. 


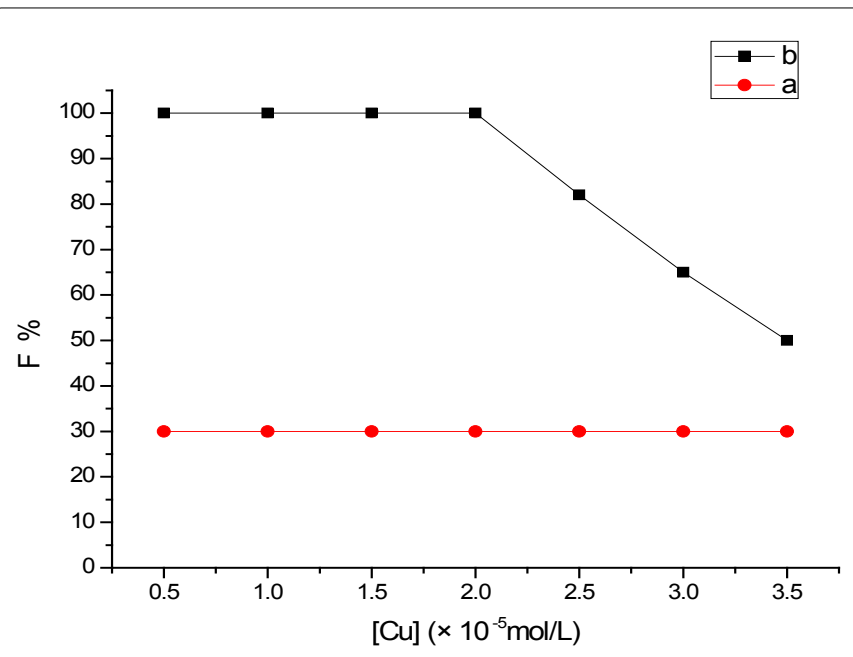

Figure 4: Floatability of different concentrations of $\mathrm{Cu}(\mathrm{II})$ at $\mathrm{pH} 4 \mathrm{a}) \ln$ the absence of NaPAR, b) In the presence of $4 \times 10^{-5} \mathrm{~mol} \mathrm{I}^{-1} \mathrm{NaPAR}$ using $2 \times 10^{-4}$ mol l-1 $\mathrm{HOL}$.

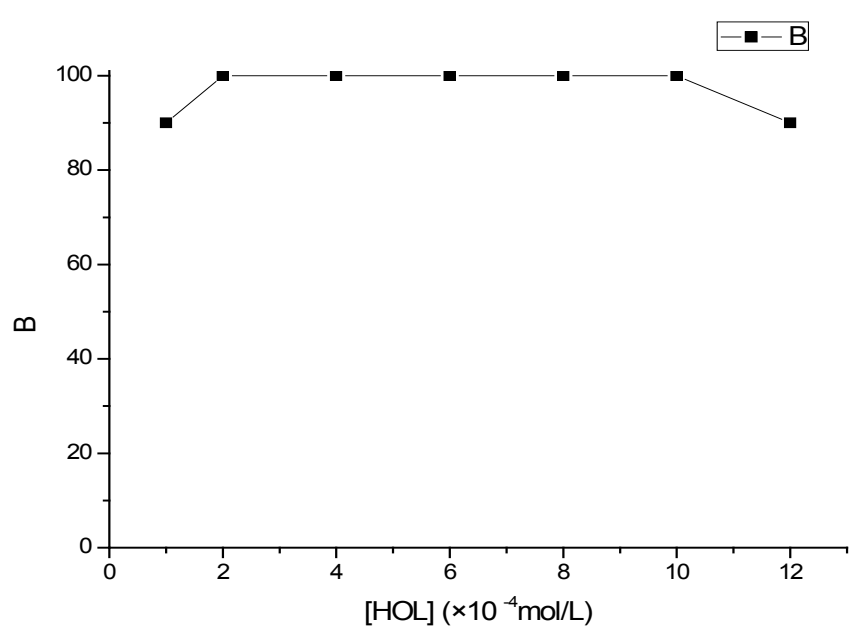

Figure 5: Floatability of $\mathrm{Cu}(\mathrm{II}), 2 \times 10^{-5} \mathrm{~mol} \mathrm{I}^{-1}$ vs. $\mathrm{HOL}$ concentration: a) In the absence of NaPAR and b) In the presence of $2 \times 10^{-4} \mathrm{~mol} \mathrm{I}^{-1} \mathrm{NaPAR}$ at $\mathrm{pH} 4$.

$\left.10^{-4} \mathrm{~mol} \mathrm{l}^{-1}\right)$. Hence, one can predict that the interfering effects may be due to complex formation which is accompanied by a decrease in the ligand concentration. Consequently, masking of the interfering effects by adding excess NaPAR offers a highly selective procedure for the separation and determination of microamounts of $\mathrm{Cu}(\mathrm{II})$ in various complex materials, like environmental, drug and biological samples.

Stoichiometry: Job's [37] method of continuous variation was applied to identify the stoichiometry of $\mathrm{Cu}$-NaPAR complex formed at $\mathrm{pH} 4.0$ in aqueous solution. The data obtained indicate the formation of $1: 2(\mathrm{Cu}: \mathrm{NaPAR})$ at $\mathrm{pH} 4.0$ with $\lambda_{\text {max }}$ at $510 \mathrm{~nm}$.

Analytical figure of merits: Beer's law is obeyed up to $5 \times 10^{-5} \mathrm{~mol}$ $\mathrm{l}^{-1}$. The molar absorptivities are $5.3 \times 10^{4}$ and $6.1 \times 10^{5} \mathrm{~mol}^{-1} \mathrm{~cm}^{-1}$ for $\mathrm{Cu}-\mathrm{NaPAR}$ and $\mathrm{Cu}-\mathrm{NaPAR}-\mathrm{HOL}$ species in the aqueous and scum, respectively. The regular enhancement in the absorbances and the higher molar absorptivity value in the presence of HOL could be attributed to the selective separation of $\mathrm{Cu}-\mathrm{NaPAR}$ using the HOL surfactant. Although the complex is formed in the aqueous solution and obeys Beer's law, its absorbance and $\in$ values are very low. Also,
Beer's law is obeyed in a very narrow concentration range. These defects may favor the determination of copper after pre-concentration. The limit of detection, which was calculated as the concentration that gives a reading equal to twice the standard deviation of a series of ten determinations taken with solutions of concentrations, which are close to the level of the blank, was found to be $2.5 \times 10^{-7} \mathrm{~mol} \mathrm{l}^{-1}$. Also, in this concern a fixed quantity of $\mathrm{Cu}$ (II) was taken and added to different aqueous volumes. It was found that $7.5 \times 10^{-7} \mathrm{~mol} \mathrm{l}^{-1}$ of $\mathrm{Cu}$ (II) was quantitatively separated and determined from different volumes up to $1 \mathrm{~L}$ using a definite type of flotation cells. This means that $7.5 \times 10^{-7}$ mol $\mathrm{l}^{-1}$ of $\mathrm{Cu}(\mathrm{II})$ can be safely separated and spectrophotometrically determined by such a procedure from a one-liter solution into $20 \mathrm{ml}$ of $\operatorname{HOL}\left(2 \times 10^{-4} \mathrm{~mol} \mathrm{l}^{-1}\right)$ with a preconcentration factor of 50 .

\section{Characterization of $\mathrm{Cu}(\mathrm{II})$-NaPAR complexes}

The $\mathrm{Cu}(\mathrm{II})$-NaPAR complexes isolated in the aqueous solution and oleic acid were characterized by infra-red spectral studies. The IR spectra of the free ligand and its metal chelate were carried out in the $4000-400 \mathrm{~cm}^{-1}$ range, Figure 8 . The characteristic findings can

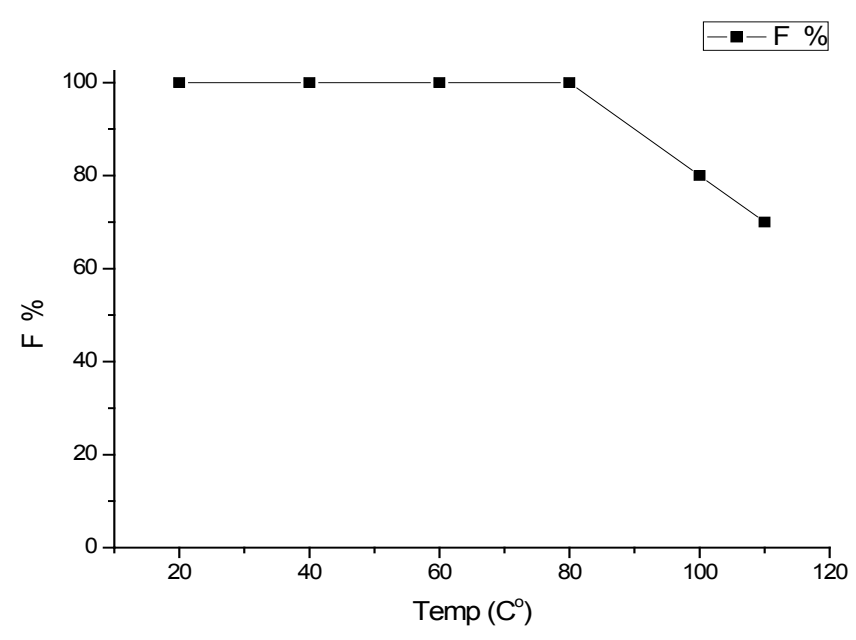

Figure 6: Effect of temperature on the separation efficiency of $2 \times 10^{-5} \mathrm{~mol} \mathrm{I}^{-1}$ $\mathrm{Cu}(\mathrm{II})$ at $\mathrm{pH} 4.0$ in the presence of $4 \times 10^{-4} \mathrm{~mol} \mathrm{I}^{-1} \mathrm{NaPAR}$ using $2 \times 10^{-4} \mathrm{~mol} \mathrm{I}^{-1}$ HOL.

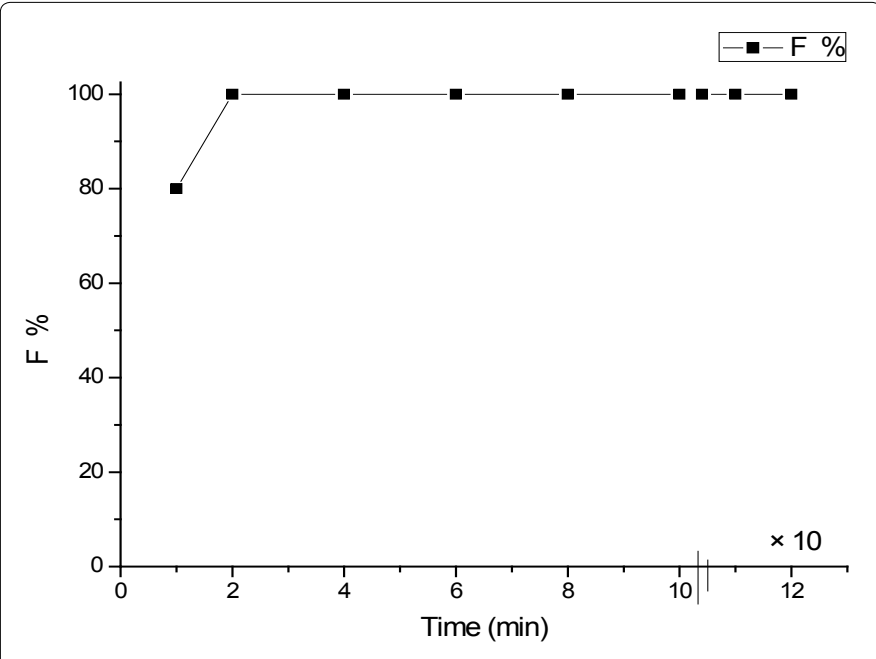

Figure 7: Effect of time on the separation efficiency of $2 \times 10^{-5} \mathrm{~mol} \mathrm{I}^{-1} \mathrm{Cu}(\mathrm{II})$ at $\mathrm{pH}$ 4.0 in the presence of $4 \times 10^{-4} \mathrm{~mol} \mathrm{I}^{-1} \mathrm{NaPAR}$ using $2 \times 10^{-4} \mathrm{~mol} \mathrm{l}^{-1} \mathrm{HOL}$ 
be summarized as follow: The IR spectrum of the ligand (Figure 8a) [38] shows a broad band at $3446 \mathrm{~cm}^{-1}$, which can be attributed to the phenolic $\mathrm{OH}$ group. This band is still broad in complex, which renders it difficult to attribute to the involvement of phenolic $\mathrm{OH}$ group in coordination. The involvement of the deprotonated phenolic $\mathrm{OH}$ group in chelation is confirmed by the shift of the $\mathrm{v}(\mathrm{C}-\mathrm{O})$ stretching band, observed at $1186 \mathrm{~cm}^{-1}$ in the free ligand, to the extent of 1118 $\mathrm{cm}^{-1}$ in the complex. The $\mathrm{v}(\mathrm{N}=\mathrm{N})$ stretching band in the free ligand is observed at $1592 \mathrm{~cm}^{-1}$. This band is shifted to lower frequency values upon complexation suggesting coordination via the azo group $(\mathrm{M}-\mathrm{N})$ $[18,19]$. The IR spectrum of the ligand revealed a sharp band at 1632 $\mathrm{cm}^{-1}$ due to $\mathrm{v}(\mathrm{C}=\mathrm{N})$ of the $\mathrm{N}_{3}$ pyridyl azo nitrogen. This band is shifted to lower frequencies in the complex indicating that it has been affected upon coordination to the metal ions $[39,40]$. The pyridine ring vibrations at $1467 \mathrm{~cm}^{-1}$ in ligand disappeared in the spectra of complex, suggesting involvement of pyridine nitrogen in bonding $[40,41]$. In the far-IR spectra of all complexes, the non-ligand bands observed at 475 and $447 \mathrm{~cm}^{-1}$ region can be assigned to the $v$ $(\mathrm{M}-\mathrm{N})$ stretching vibrations of the azo and $\mathrm{N}_{3}$ pyridylazo nitrogen, respectively. Conclusive evidence regarding the bonding of oxygen to the metal ions is provided by the occurrence of bands at $535 \mathrm{~cm}^{-1}$ as the result of $v(\mathrm{M}-\mathrm{O})[38,42,43]$.

Oleic acid initiates to dissociate at $\mathrm{pH} \geq 5$.2. Consequently, oleic acid can interact with other system, through hydrogen bonding, whichever by its undissociated or dissociated form dependent on the $\mathrm{pH}$ of the medium. The infrared spectrum of the complex formed in oleic acid layer (Figure 8c) is different from that formed in the aqueous solution (Figure $8 \mathrm{~b}$ ). The appearance of the bands at $\sim 1820,2050$ and $2400 \mathrm{~cm}^{-1}$ in the spectrum of the $\mathrm{Cu}-\mathrm{NaPAR}-\mathrm{HOl}$ is due to $v(\mathrm{O}-\mathrm{H} \cdots \mathrm{O})$ vibrations of the intermolecular hydrogen bonding. The absorption bands corresponding to the oleic acid surfactant at $1710 \mathrm{~cm}^{-1}$ are due to $\mathrm{v}(\mathrm{C}=\mathrm{O})$ vibration of carboxylate ion of oleic acid (Figure 7c). Another band is also observed at $1462 \mathrm{~cm}^{-1}$ assigned to $\mathrm{v}_{\mathrm{s}} \mathrm{COO}^{-}$vibration.

Careful comparison of the IR spectrum of the of the NaPAR complexes, isolated from the aqueous solution and surfactant layer with that of NaPAR indicated that NaPAR may act as a tridentate ligand complexing with the $\mathrm{Cu}(\mathrm{II})$ ion through the ortho hydroxyl group, the azo nitrogen nearest to the phenolic ring and the heterocyclic nitrogen atom.

So, the proposed mechanism may be through intermolecular hydrogen bonding. Therefore, the system $\mathrm{Cu}$ - NaPAR - HOL become hydrophobic and floated with air bubbles to the surface.

\section{Flotation mechanism}

The role of surfactant is very important in studies concerning separation via flotation. The nature of the interaction between oleic acid surfactant and the complex formed (Cu-NaPAR) must be studied to approach the actual mechanism of floatation.

The proposed mechanism may proceed through a physical interaction or by forming a hydrogen bond between the hydrophilic part of HOL and the active sites in the ligand complex, or by an interaction between oleic acid and the complex, formed in solution, through a coordinate bond forming a self-floatable (Cu-NaPAR-HOL) species. In every case, the hydrophobic part of the surfactant attaches to air bubbles and floats separating the analyte-containing species.

\begin{tabular}{|c|c|c|}
\hline \multirow{2}{*}{ Salt } & Concentration, (M) & $\mathbf{F}(\mathbf{\%})$ \\
\hline \multirow{3}{*}{$\mathrm{NaCl}$} & 0.1 & 100 \\
\cline { 2 - 3 } & 0.01 & 100 \\
\hline \multirow{2}{*}{$\mathrm{KCl}$} & 0.001 & 100 \\
\hline \multirow{2}{*}{$\mathrm{K}$} & 0.1 & 98.1 \\
\hline \multirow{2}{*}{$\mathrm{CaCl} 2$} & 0.01 & 100 \\
\hline & 0.001 & 100 \\
\hline & 0.1 & 92.5 \\
\hline
\end{tabular}

Table 1: Effect of lonic Strength on the Floatability of $2.0 \times 10-5 \mathrm{M}$ of $\mathrm{Cu}(\mathrm{II})$ using $1.0 \times 10-4 \mathrm{M}$ of NaPAR, $1.0 \times 10-4 \mathrm{M} \mathrm{HOL}$ at pH 4.

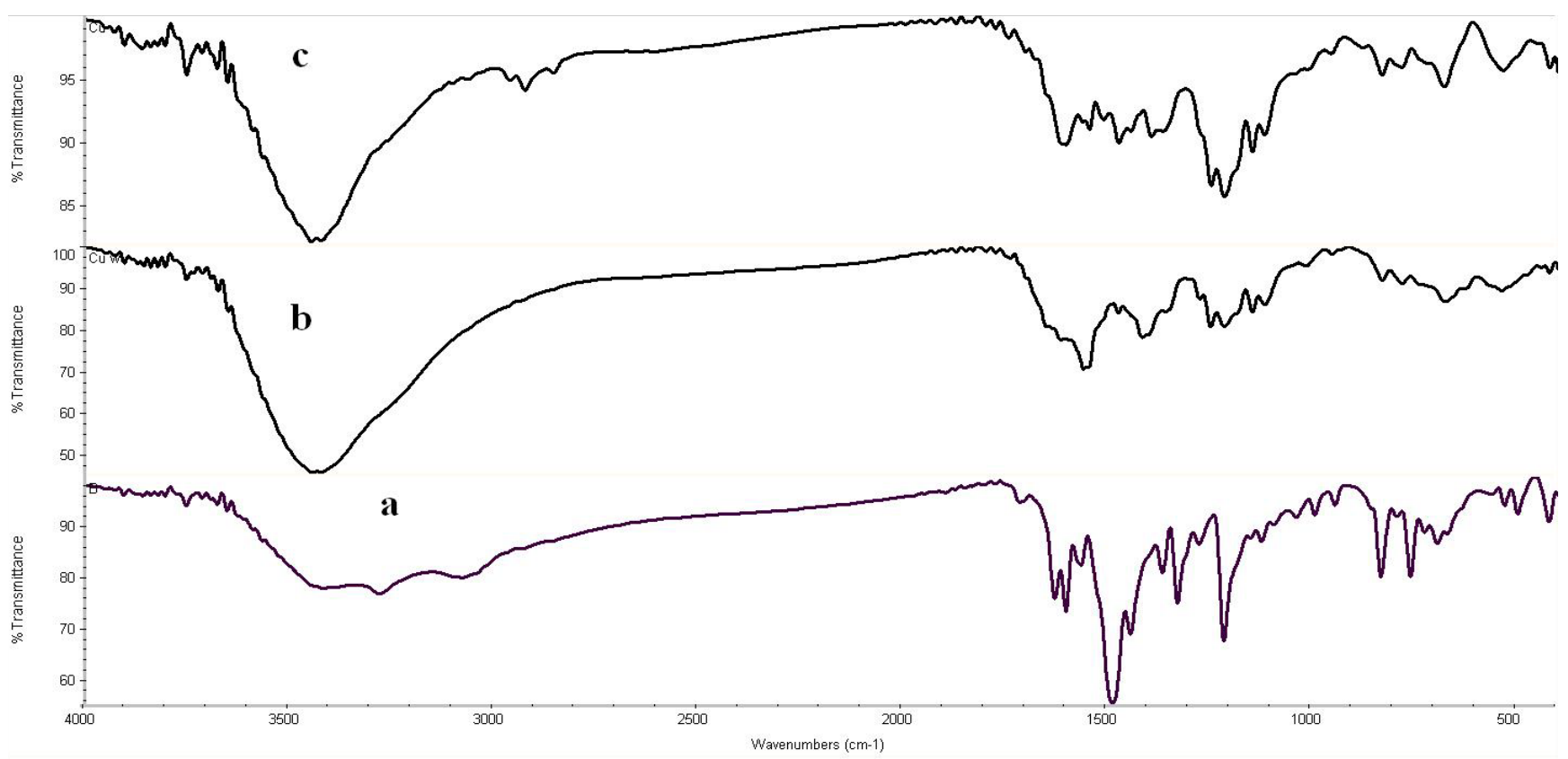

Figure 8: Infrared spectra of a) $\mathrm{NaPAR}$ in $\mathrm{KBr}$, b) $\mathrm{Cu}(\mathrm{II})-\mathrm{NaPAR}$ isolated in aqueous solution in $\mathrm{KBr}$ and c) $\mathrm{Cu}(\mathrm{II})-\mathrm{NaPAR}-\mathrm{HOL}$ isolated in oleic acid in $\mathrm{KBr}$. 
Citation: AkI MA, Bekheit MM, Salih QM (2015) Surfactant Assisted Separation-Spectrophotometric Procedure for the Trace Analysis of Copper (II) in Drug and Water Samples Using a Heterocyclic Pyridyl Azo Dye. Pharm Anal Acta 6: 421. doi:10.4172/21532435.1000421

Page 6 of 7

In the present study, the flotation mechanism is proposed to proceed through hydrogen bonding between $\mathrm{HOL}$ and $\mathrm{Cu}-\mathrm{NaPAR}$ system. This confirmation is extracted from the following experimental data and observations:

1) The floated species (Cu-NaPAR-HOL) have the same $\lambda$ max as those formed in aqueous solution (Cu-NaPAR).

2) The color intensity of the scum layer was not affected by time. It should be noted that the color fading of the sub late begins after at least $72 \mathrm{hrs}$ after flotation; such a time is more than enough for our determination. 3) The data in Fig. 6 show that increasing the temperature up to $80 \mathrm{C}$ does not affect the separation percentage, reflecting that the hydrogen bond between $\mathrm{HOL}$ and the $\mathrm{Cu}-\mathrm{NaPAR}$ complex is not destroyed by heating. 4) The IR spectra of the $\mathrm{Cu}$ NaPAR complex isolated in the absence and presence of HOL are not identical (Figure $8 \mathrm{~b}$ and $8 \mathrm{c}$ ), reflecting the fact that there is some hydrogen contribution between $\mathrm{HOL}$ and the $\mathrm{Cu}-\mathrm{NaPAR}$ complex .

In conclusion, all of the mentioned data confirm the formation of hydrogen bonding between HOL and $\mathrm{Cu}-\mathrm{NaPAR}$ system forming a selffloatable (Cu-NaPAR-HOL) species. In such cases, the hydrophobic part of the surfactant attaches to air bubbles and floats, thus separating the analyte-containing species.

\section{Application}

\section{Water samples}

The recovery of definite amounts of $\mathrm{Cu}(\mathrm{II})$ added to different water samples was studied. To $100 \mathrm{ml}$ aliquots of pure uncontaminated and filtered water samples definite concentrations of $\mathrm{Cu}$ (II) were added and the $\mathrm{pH}$ was adjusted to $\sim 4$. After flotation, the concentration of $\mathrm{Cu}$ (II) was determined spectrophotometrically and confirmed by atomic absorption spectrometry (AAS). The recovery $\%$ is $>95 \%$, Table 2 .

\begin{tabular}{|c|c|c|c|c|c|}
\hline \multirow{2}{*}{$\begin{array}{l}\text { Type of water } \\
\text { (location) }\end{array}$} & \multirow{2}{*}{$\begin{array}{l}\mathrm{Cu}(\mathrm{II}) \text { added } \\
(\mathrm{mM})\end{array}$} & \multicolumn{2}{|l|}{ AAS } & \multicolumn{2}{|c|}{ Spectrophotometry } \\
\hline & & Recovery, \% & RSD, \% & Recovery, \% & RSD, \% \\
\hline \multirow{4}{*}{ Distilled w ater } & 0 & 0.0 & 0.0 & 0.0 & 0.0 \\
\hline & 5.0 & 99.8 & 1.80 & 99.7 & 1.6 \\
\hline & 10.0 & 95.8 .0 & 1.5 & 99.0 & 2.8 \\
\hline & 15 & 100.0 & 2.0 & 98.5 & 1.0 \\
\hline \multirow{4}{*}{$\begin{array}{l}\text { Tap w ater } \\
\text { (Our laboratory) }\end{array}$} & 0 & 0.0 & 0.0 & 0.0 & 0.0 \\
\hline & 5.0 & 99.6 & 1.6 & 99.6 & 2.3 \\
\hline & 10.0 & 99.8 & 2.8 & 100 & 1.5 \\
\hline & 15 & 99.4 & 1.0 & 100.0 & 2.0 \\
\hline \multirow{4}{*}{$\begin{array}{l}\text { Nile w ater } \\
\text { (Mansoura } \\
\text { City) }\end{array}$} & 0.0 & 0.0 & 0.0 & 0.0 & 0.0 \\
\hline & 5 & 99.9 & 2.3 & 99.7 & 1.6 \\
\hline & 10 & 99.4 & 1.5 & 99.8 & 2.1 \\
\hline & 15 & 99.6 & 2.0 & 100 & 1.8 \\
\hline \multirow{4}{*}{$\begin{array}{l}\text { Sea w ater } \\
\text { (Demiate } \\
\text { City) }\end{array}$} & 0.0 & 0.0 & 0.0 & 0.0 & 0.0 \\
\hline & 5 & 99.8 & 2.3 & 99.7 & 2.5 \\
\hline & 10 & 100.0 & 1.5 & 99.8 & 1.9 \\
\hline & 15 & 100.0 & 2.00 & 100 & 1.4 \\
\hline \multirow{4}{*}{$\begin{array}{l}\text { Sea w ater } \\
\text { (Ras El-Barr) }\end{array}$} & 0.0 & 0.0 & 0.0 & 0.0 & 0.0 \\
\hline & 5 & 99.6 & 2.5 & 99.7 & 2.3 \\
\hline & 10 & 100 & 1.9 & 99.8 & 1.5 \\
\hline & 15 & 100 & 1.4 & 100 & 2.00 \\
\hline
\end{tabular}

Table 2: Recovery of $\mathrm{Cu}(\mathrm{II})$ spiked in natural $\mathrm{w}$ ater samples after flotation using $1.0 \times 10-3 \mathrm{M} \mathrm{NaPAR}$ and $1.0 \times 10-4 \mathrm{M} \mathrm{HOL}$ at $\mathrm{pH} \sim 4$ at $25^{\circ} \mathrm{C}(\mathrm{n}=3)$.

\begin{tabular}{|c|c|c|c|c|c|}
\hline \multicolumn{2}{|c|}{$\mathrm{Cu}(\mathrm{II}), \mathrm{mg}$} & \multirow{2}{*}{$\begin{array}{l}\text { Abs. } \\
\text { error }\end{array}$} & \multirow{2}{*}{$\begin{array}{c}\mathbf{R} . \\
\text { error }\end{array}$} & \multirow{2}{*}{ SD } & \multirow{2}{*}{ RSD, \% } \\
\hline Certified & Found & & & & \\
\hline 2.0 & 2.05 & 0.18 & 0.018 & 0.013 & 0.13 \\
\hline 3.0 & 2.95 & 0.23 & 0.044 & 0.02 & 0.38 \\
\hline
\end{tabular}

Table 3: Analysis of $\mathrm{Cu}(\mathrm{II})$ in some drug samples after flotation using $1 \times 10-2 \mathrm{~mol}$ L-1 NaPAR and $1 \times 10-4 \mathrm{~mol} \mathrm{L-1} \mathrm{HOL} \mathrm{at} \mathrm{pH} 4$ at $25^{\circ} \mathrm{C}(\mathrm{n}=3)$.

\section{Drug samples}

Analysis of $\mathrm{Cu}(\mathrm{II})$ in real drug samples under the recommended conditions is shown in Table 3 with a relative standard deviation, RSD, $<1.0 \%$.

\section{References}

1. Duruibe JO, Ogwuegbu MOC, Egwurugwu JN (2007) Heavy Metal Pollution and Human Biotoxic Effects. International Journal of Physical Sciences 2: 112118

2. Valko M, Morris H, Cronin MT (2005) Metals, toxicity and oxidative stress. Curr Med Chem 12: 1161-1208.

3. Judith TZ, Peter T, Thomas T (1998) Immunotoxicology of Environment Occupational Metals, School of Environment Occupational Metals, School of Medicine, New York.

4. Sharma BK (1997) Environmental Chemistry, Goel Publishing House, Meerut, India.

5. Jankowski K, Yao J, Kasiura K, Jackowska A, Sieradzka A (2005) Multielement Determination of Heavy Metals in Water Samples by Continuous Powder Introduction Microwave-Induced Plasma Atomic Emission Spectrometry after Preconcentration on Activated Carbon. Spectrochimica Acta Part B 60: 369375.

6. Ceratti S, Moyano S, Marrero J, Smichowski P, Martinez LD (2005) On-Line Pre-concentration of Nickel on Activated Carbon Prior to Its Determination by Vapor Generation Associated to Inductively Coupled Plasma Optical Emission Spectrometry. Journal of Analytical Atomic Spectrometry 20: 559-561.

7. Umashankar V, Radhamani R, Ramadoss K, Murty DSR (2002) Simultaneous Separation and Pre-concentration of Trace Elements in Water Samples by Coprecipitation on Manganese Dioxide Using D-Glucose as Reductant for KMnO4. Talanta 57: 1029-1038.

8. Doner G, Ege A (2005) Determination of Copper, Cadmium and Lead in Seawater and Mineral Water by Flame Atomic Absorption Spectrometry after Co-precipitation with Aluminum Hydroxide. Analytica Chimica Acta: 547: 14-17.

9. Kumar M, Rathore DPS, Singh AK (2002) Pre-concentration of Lead with Amberlite XAD-2 and Amberlite XAD-7 Based Chelating Resins for Its Determination by Flame Atomic Absorption Spectrometry. Talanta 56: 735-744.

10. Jain VK, Mandalia HC, Gupte HS, Vyas DJ (2009) Azocalix[4]pyrrole Amberlite XAD-2: New Polymeric Chelating Resins for the Extraction, Pre-concentration and Sequential Separation of $\mathrm{Cu}(\mathrm{II}), \mathrm{Zn}(\mathrm{II})$ and $\mathrm{Cd}(\mathrm{II})$ in Natural Water Samples. Talanta 79: 1331-1340

11. Gholivand MB, Mohammadi M, Khodadadian M, Rofouei MK (2009) Nove platinum(II) selective membrane electrode based on 1,3-bis(2-cyanobenzene) triazene. Talanta 78: 922-928.

12. Li XG, Ma XL, Huang MR (2009) Lead(II) ion-selective electrode based on polyaminoanthraquinone particles with intrinsic conductivity. Talanta 78: 498505.

13. Camino M, Bagur MG, Sandchez-Vinas M, Gazquez D, Romero R (2002) Multivariate Optimization of Solvent Extraction of $\mathrm{Cd}(\mathrm{II}), \mathrm{Co}(\mathrm{II}), \mathrm{Cr}(\mathrm{VI}), \mathrm{Cu}(\mathrm{II})$, $\mathrm{Ni}(\mathrm{II}), \mathrm{Pb}(\mathrm{II})$ and $\mathrm{Zn}(\mathrm{II})$ as Dibenzyldithiocarbamates and Detection by AAS. Anal At Spectrom 16: 638-642.

14. Silva EL, dos Roldan SP, Gin MF (2009) Simultaneous Pre-concentration of Copper, Zinc, Cadmium, and Nickel in Water Samples by Cloud Point Extraction Using 4-(2- Pyridylazo)-Resorcinol and Their Determination by Inductively Coupled Plasma Optic Emission Spectrometry. J Hazard Mater 171: 1133-1138.

15. Kabil MA, AkI MA, Khalifa ME (1999) Selective Flotation Spectrophotometric Procedure for trace Analysis of Palladium in different matrices. Anal Sci 15 433-438. 
Citation: AkI MA, Bekheit MM, Salih QM (2015) Surfactant Assisted Separation-Spectrophotometric Procedure for the Trace Analysis of Copper (II) in Drug and Water Samples Using a Heterocyclic Pyridyl Azo Dye. Pharm Anal Acta 6: 421. doi:10.4172/21532435.1000421

16. Kabil MA, AkI MA, Abdallah AM, Ismael D (2000) Selective Separation-Flotation of Hafnium from Zirconium and their determination in real samples. Anal Sci 16 : 713-718.

17. Khalifa ME, AkI MA, Ghazy SE (2001) Selective Flotation-Spectrophotometric Determination of Trace Copper (II) in Natural Waters, Human Blood and Drug Samples using Phenanthraquinone Monophenylthiosemicarbazone. Chem Pharm Bull (Japan) 49: 664-668.

18. MA Akl, MA Kabil, Abdallah AM, Ismael D (2001) Use of Eriochrome Cyanine $\mathrm{R}(\mathrm{ECR})$ for Separation-Flotation and micro determination of Hafnium and Zirconium in real Samples. Sep Sci and Tech (USA) 36: 2747-2760.

19. AkI MA, Khalifa ME, Ghazy SE, Hassanien MM (2002) Selective flotationseparation and spectrophotometric determination of cadmium using phenanthraquinone monophenythiosemicarbazone. Anal Sci 18: 1235-1240.

20. AkI MA, Kabil MA, Abdalla AM, Ismael DS (2003) Flotation and sectrophotometry: Thorough investigation and application to the spectrophotometric determination of the total amounts of lanthanum and yttrium in natural samples. Bull Chem Soc Jpn 76: 1543.

21. Abdalla AM, Kabil MA AkI MA, Ismael DS (2004) Simultaneous preconcentration flotation separation and spectrophotometric determination of thorium, lanthanum and yttrium in some geological and environmental samples. JICS 1: 79.

22. Akl MA El-Asmy AA Yossef WM (2005) Separation via flotation, spectrophotometric speciation, and determination of vanadium(IV) in wastes of power stations. Anal Sci 21: 1325-1335.

23. AKI MA, Ismael DS, Elasmy AA (2006) Precipitate Flotation-Separation, Speciation and Hydride Generation Atomic Absorption Spectrometric Determination of Selenium(IV) in Food Stuffs. Microchemical Journal (USA) 83: $61-69$

24. MA Akl (2006) The Use of Phenathraquinone Monophenyl Thiosemicarbazone for Preconcentration, Ion flotation and Spectrometric Determination of Zinc(II) in Human Biofluids and Environmental Samples. Bulletin of the Korean Chemical society (South Korea) 27: 725.

25. Ahmed FA El-Asmy, Wafaa M Yousef, Magda Ali AkI Flotation (2010) Speciation and determination of iron(III) using aluminon in water, real samples and wastes of power stations. European Journal of Chemistry 1: 189-194.

26. Magda A Akl, Dalia S Isamil, Bakir Jeragh, Ahmed A El-Asmy (2014) Flotation separation and spectrophotometric determination of Sc3+ in certified materials and different water resources. Journal of Scientific Research and Reviews 3 : 008-017.

27. Magda A Akl, Mostafa MM and Elbadrawy Z (2014) Separation via Flotation and Spectrometric Determination of Copper(II) in Environmental Samples using a Newly Synthesized Girard T Derivative. Chem Sci J.

28. Anastas P, Eghbali N (2010) Green chemistry: principles and practice. Chem Soc Rev 39: 301-312.

29. S Shibata (1972) Chelates in analytical chemistry. New York: Marcel Dekker 4: 207
30. Reddy BK, Kumar JR, Reddy KJ, Sarma LS, Reddy AV (2003) A Rapid and Sensitive Extractive Spectrophotometric Determination of Copper (II) in Pharmaceutical and Environmental Samples Using Benzildithiosemicarbazone. Anal Sci 19: 423

31. Jadhav VA, Vandre AG (1995) Extractive spectrophotometric determination of copper (II) in water and alloy samples with 3-methoxy-4-hydroxy benzaldehyde4-bromophenyl hydrazone (3,4-mhbbph). J Indian Chem Soc 72: 747.

32. Hymavathi M, Devanna N, Viswanatha C (2014) Direct and derivative spectrophotometric determination of copper (ii) using a sensitive and selective chromogenic organic reagent 2-hydroxy 3,5-dimethoxy benzaldehyde thiosemicarbazone (hdmbtsc). World J pharmacy and pharmaceutical sciences 3: 1688-1695.

33. Nagalakshmi BN, Viswanatha C, Donappa N, Chandrasekhar KB (2015) A sensitive and selective chromogenic organic reagent diacetylmonoxime3-amino-4-hydroxy benzoyl hydrazone used for direct and derivative spectrophotometric determination of copper(II). Chem Sci Trans 4: 838-843.

34. Lakshmi Narayana S, Janardhan Reddy K, Adinarayana Reddy S, Sarala Y, Varada Reddy A (2008) Benzyloxybenzaldehydethiosemicarbazone: extractive spectrophotometric reagent for the determination of $\mathrm{Cu}(\mathrm{II})$ in food and water samples. Food Analytical Methods 1: 293-299.

35. Ghazy SE, Kabil MA (1994) Determination of Trace copper in Natural Waters after Selective Separation by Flotation, Bull Chem Soc Jpn 67: 2098-2102.

36. Lemlich (1972) Adsorptive Bubble Separation Techniques, Academic Press, New York.

37. Job P, Hebd CR (1925) Seances Acad Sci 180: 928.

38. Karipcin F, Kabalcilar E (2007) Spectroscopic and Thermal Studies on Solid Complexes of 4-(2-pyridylazo)resorcinol with Some Transition Metals. Acta chim. Slov 54: 242-247.

39. Omar MM, Mohamed GG (2005) Potentiometric, spectroscopic and therma studies on the metal chelates of 1-(2-thiazolylazo)-2-naphthalenol. Spectrochim Acta A Mol Biomol Spectrosc 61: 929-936.

40. Pandey G, Narang KK (2004) Synt React. Inorg Met.-Org. Chem. Synthesis Characterization, Spectral Studies, and Antifungal Activity of $\mathrm{Mn}(\mathrm{II}), \mathrm{Fe}(\mathrm{II})$ $\mathrm{Co}(\mathrm{II}), \mathrm{Ni}(\mathrm{II}), \mathrm{Cu}(\mathrm{II})$, and $\mathrm{Zn}(\mathrm{II})$ Complexes with Monosodium 4-(2-Pyridylazo) resorcinol 34: 291-311.

41. Roy R, Chattopadhyay P, C Sinha, Chattopadhyay S (1996) Synthesis, spectral and electrochemical studies of arylazopyridine complexes of palladium(II) with dioxolenes. Polyhedron 15: 3361-3369.

42. Mohamed GG, Zayed MA, El-Gamel NE (2002) Thermal and kinetic studies on solid complexes of 2-(2-benzimidazolylazo)-4-acetamidophenol with some transition metals. Spectrochim Acta A Mol Biomol Spectrosc 58: 3167-3178.

43. Zaki ZM (2000) Spectral, thermal and electrical properties of some new azo complexes. Spectrochim Acta A Mol Biomol Spectrosc 56A: 1917-1923. 